\title{
Does construction in the spawning ground improve the riverbed conditions making it suitable for spawning of the Ryukyu-ayu Plecoglossus altivelis ryukyuensis?
}

Satoshi Awata, Tetsuya Tsuruta, Shin-ichiro Abe, Toshihiko Yonezawa \& Kei’ichiro Iguchi

\begin{tabular}{|c|l|}
\hline Citation & Ichthyological Research. 67(4); 493-501 \\
\hline Issue Date & $2020-11$ \\
\hline Published & $2020-04-15$ \\
\hline Type & Journal Article \\
\hline Textversion & Author \\
\hline Rights & $\begin{array}{l}\text { C The Ichthyological Society of Japan. This is a post-peer-review, pre-copyedit version of } \\
\text { an article published in Ichthyological Research. The final authenticated version is } \\
\text { available online at: } \text { https://doi.org/10.1007/s10228-020-00745-7. } \\
\text { See Springer Nature terms of reuse for archived author accepted manuscripts (AAMs) of } \\
\text { subscription articles. } \\
\text { https://www.springer.com/gp/open-access/publication-policies/aam-terms-of-use. }\end{array}$ \\
\hline DOI & \begin{tabular}{l}
$10.1007 /$ s10228-020-00745-7 \\
\hline
\end{tabular}
\end{tabular}

Self-Archiving by Author(s) Placed on: Osaka City University Repository

Awata, S., Tsuruta, T., Abe, S. et al. Does construction in the spawning ground improve the riverbed conditions making it suitable for spawning of the Ryukyu-ayu Plecoglossus altivelis ryukyuensis?. Ichthyological Research. (2020). Doi:10.1007/s10228-020-00745-7 


\section{Does construction in the spawning ground improve the river bed conditions making it suitable for spawning of the Ryukyu-ayu Plecoglossus altivelis ryukyuensis?}

Satoshi Awata ${ }^{1,2,3}$ - Tetsuya Tsuruta ${ }^{3,4}$ Shin-ichiro Abe ${ }^{3,5}$. Toshihiko Yonezawa ${ }^{6}$ Kei'ichiro Iguchi ${ }^{3,7}$

${ }^{1}$ Laboratory of Animal Sociology, Graduate School of Science, Osaka City University, Osaka, Japan

${ }^{2}$ Sado Marine Biological Station, Faculty of Science, Niigata University, Sado, Japan ${ }^{3}$ Ueda Station, Freshwater Fisheries Research Division, National Research Institute of Fisheries Science, Fisheries Research Agency, Komaki, Ueda, Japan

${ }^{4}$ Department of Human Life and Environment, Faculty of Human Environment, Osaka Sangyo University, Daito, Japan

${ }^{5}$ College of Education, Ibaraki University, Mito, Japan

${ }^{6}$ Kagoshima Environmental Research and Service, Kagoshima, Japan

${ }^{7}$ Graduate School of Fisheries Science and Environmental Studies, Nagasaki University, Nagasaki, Japan

Satoshi Awata

sa-awata@sci.osaka-cu.ac.jp

Satoshi Awata

ORCID ID: 0000-0003-3254-7943

\section{Running head}

Spawning ground construction for Ryukyu-ayu 
Abstract Maintaining a certain number of spawning grounds for endangered fish is particularly important in rivers and streams where the environment changes drastically through floods and exploitations. Ryukyu-ayu Plecoglossus altivelis ryukyuensis is an endangered annual fish inhabiting the few streams and rivers flowing through the Amami-Oshima Island, southern Japan, and spawns in the lower reaches at sites with the specific riverbed conditions. In the island, resident volunteers along with researchers modify riverbed manually to provide conditions suitable for the natural spawning of the fish every year. This study investigated the effects of these activities on the riverbed conditions and consequently on the spawning by Ryukyu-ayu in two rivers. Our results showed that riverbed hardness and the amount of silt significantly decreased in the modified areas, but not in the adjacent unmodified areas. In one of the two rivers, the modification suppressed the settlement of net-spinning caddisfly larvae Stenopsyche schmidi that promote consolidation of the riverbed. The riverbed conditions in the modified areas were similar to those in the sites where $P$. a. ryukyuensis indeed spawned. These results suggest that manual modification is efficient in improving riverbed conditions for the spawning of Ryukyu-ayu. However, the eggs of the fish were not found at the modified areas in both rivers. It will be necessary to develop effective and practical ways of selecting sites for modification without obstructing the natural spawning in this fish.

Keywords Endangered fish $\cdot$ Spawning ground $\cdot$ Riverbed hardness $\cdot$ Silt $\cdot$ Caddisfly 


\section{Introduction}

Ryukyu-ayu Plecoglossus altivelis ryukyuensis Nishida, a subspecies of ayu $P$. a. altivelis Temmink \& Schlegel, is an amphidromous fish having an annual life history (Nishida 1988; Shinomiya 1997; Aritomi et al. 2017; Murase et al. 2018). This species is currently listed in the Japanese Red Data Book as a critically endangered fish found only in Amami-Oshima Island and Okinawa Island in southern Japan (Nishida 1988; Nishida et al. 1992; Shinomiya 2003; Tachihara 2015). Wild populations in the Okinawa Island have gone extinct since the late 1970 s due to the destruction of riverine environment, but artificial seeding of dams and rivers in Okinawa Island using stocks from the Amami-Oshima Island have since been undertaken (Kawanabe 1972; Nishida et al. 1992; Shinomiya 2003; Tachihara 2015). The extant wild populations inhabiting Amami-Oshima Island have also decreased considerably due to human activities such as river modification, environmental destruction, and overfishing (Shinomiya 1997, 2003; Tachihara 2015). The population of this fish has been estimated at about 10,000-20,000 individuals in recent years (Tachihara 2015).

Under these circumstances, many researchers have made efforts to increase the population of Ryukyu-ayu and to conserve the river environment in the island. Activities undertaken to protect the Ryukyu-ayu include the prohibition of fishing and the setting of a closed season for river modification (Shinomiya 2003; Tachihara 2015). Ryukyu-ayu spawns in the lower reach of rivers (Nishida and Uchimura 1987; Tsuruta et al. 2009). Reduction of spawning grounds due to river modification is considered to be one of the important factors for the drastic reduction of Ryukyu-ayu. Hence, resident volunteers and researchers together created a spawning ground by alternating the riverbed before the spawning season every year (Nishida and Uchimura 1987; Nishida et al. 1992; Tsuruta et al. 2009). However, no signs of population recovery have been observed yet. 
Different from the situation in Ryukyu-ayu P. a. ryukyuensis, the subspecies ayu $P$. a. altivelis is not an endangered fish (Ministry of Environment 2015). Wild populations of ayu, however, have also declined due to environmental deterioration and overfishing (Iguchi 1997). Since ayu is a commercially important fish in Japan, spawning grounds for ayu have been created in many rivers since the 1940s to improve the catch of ayu. Results from these studies have been reviewed by the National Federation of Inland Water Fisheries Cooperative Associations (1993). According to this review, in some cases the spawning ground construction is highly effective, but in other cases it is not effective or its effect is obscure. However, even these positive results appear to be weakened because of the lack of control experiments in many studies. Furthermore, many of these studies have only assessed whether spawning occurred in the constructed areas, and a few have investigated changes in the physical environment of the river due to the construction. Although not many reports on the spawning ground construction in ayu have been published since 1993, most of them have examined the physical environment of the rivers (e.g., substrate size, riverbed hardness, water depth, and current velocity) as well as spawning by ayu (Kondo et al. 2008, 2011; Hyodo et al. 2014; Takahashi et al. 2015, and references therein; Izumi et al. 2016). In all cases, however, spawning ground is constructed in large rivers using bulldozers and power shovels. In contrast, spawning ground construction is carried out manually using scoops and hoes in the small rivers in the Amami-Oshima Island (Nishida and Uchimura 1987; Nishida et al. 1992; Tsuruta et al. 2009). In addition, body size of sexually mature Ryukyu-ayu is much smaller than that of ayu (Nishida and Uchimura 1987; Awata et al. 2012). It is widely known that the body size of ayu is related to the selection of the spawning site (e.g., Ishida 1961, 1962; Tsuruta et al. 2009). Considering these facts, the spawning ground construction method for ayu is unlikely to be applicable for Ryukyu-ayu. However, no study has so far investigated the effect of the spawning ground construction on the spawning of Ryukyu-ayu, 
although their spawning site condition has been described in previous studies (Tsuruta et al. 2009; Ohtsuki et al. 2013).

In this study, we assessed whether the spawning ground construction had positive effects on the riverbed environment and consequently on the spawning by Ryukyu-ayu. We conducted field experiments in two rivers of the Island wherein we established spawning grounds by tilling the riverbed and then compared the riverbed environment between the constructed areas and unconstructed control areas. Tsuruta et al. (2009) have reported that the spawning sites of the Ryukyu-ayu are found in the transition zones between riffle and run, in the lower reach of the river. Further, they reported that the riverbed hardness is one of the most important factors affecting the presence of eggs of the Ryukyu-ayu on the bottom substrate (also see Ohtsuki et al. 2013). Furthermore, caddisfly larvae Stenopsyche schmidi, which construct a protective portable case using sticky silk fibers as an adhesive tape, appears to promote consolidation of the riverbed, which is strongly related to the riverbed hardness (Tsuruta et al. 2009). Therefore, we assessed whether the spawning ground construction reduced riverbed hardness and caddisfly larvae numbers. We also examined whether the construction appeared to reduce silt, which would greatly affect the survival of Ryukyu-ayu eggs, as has been reported for many freshwater fishes (e.g., Newcombe and MacDonald 1991 for review).

\section{Materials and methods}

Study streams. Fieldwork was carried out on the Amami-Oshima Island, Kagoshima, Japan in the Yakugachi River that discharges into the Pacific Ocean, and in the Kawauchi River that discharges into the East China Sea (Fig. 1a). The length of these rivers is $16 \mathrm{~km}$ and 13 
$\mathrm{km}$, respectively. Ryukyu-ayu is abundant in both rivers, where spawning is observed every year (Nishida et al. 1992; Kishino and Shinomiya 2004; Tsuruta et al. 2009; Ohtsuki et al. 2013). Previous studies have shown that the population of this subspecies on the Pacific side genetically differs greatly from that on the East China Sea side in the island (Sawashi and Nishida 1994; Takagi et al. 1999; Ikeda et al. 2003; Takeshima et al. 2005). Therefore, spawning sites in both rivers have an extremely important role to play in sustaining the two populations of the island.

Potential spawning site investigation. The spawning season of Ryukyu-ayu generally starts in November and extends until March, and peaks in January (Nishida and Uchimura 1987; Kishino and Shinomiya 2003, 2004). In addition, one of the authors (TY) checked for the presence of Ryukyu-ayu eggs on the bottom substrates, once or twice a month from October to March each year for almost twenty years since 2001, in the Yakugachi and Kawauchi Rivers. Therefore, our field study was conducted between November 2011 and January 2012. A previous study has shown that Ryukyu-ayu prefer shallow riffles and a fast flow in the lower reach of rivers as spawning sites (Tsuruta et al. 2009). To establish experimental and control areas, we investigated a number of riffles and their positions on November 24 and 25, 2011 in the lower reach of the Yakugachi and the Kawauchi Rivers (Fig. 1b). There were ten and three riffles within $450 \mathrm{~m}$ and $80 \mathrm{~m}$ length of the lower reaches in the Yakugachi and the Kawauchi Rivers, respectively. We checked whether eggs were attached on the bottom substrates in the 13 riffles by picking up pebbles more than 30 times from the riverbed for more than $30 \mathrm{~min}$ in each riffle. One of the authors (SAw) snorkeled in an upstream direction in the lower reach of the two rivers for approximately $30 \mathrm{~min}$ between 1230 and $1700 \mathrm{~h}$ and the standard length (SL, to the nearest $5 \mathrm{~mm}$ ) of each Ryukyu-ayu was estimated visually. Ryukyu-ayu in this season were in schools, all of which (Yakugachi River: $n=55$; Kawauchi River: $n=30$ ) were measured for 
their SL during snorkeling. Water temperature was $17.1-18.1{ }^{\circ} \mathrm{C}$ in Yakugachi River and $17.8^{\circ} \mathrm{C}$ in Kawauchi River on November 24 and 25, 2011.

Establishment of experimental and control areas. Ryukyu-ayu eggs were found on November 25, 2011 in the Yakugachi River, but not in the Kawauchi River. We did not choose the riffles that were already used as a spawning site by the Ryukyu-ayu and those that were judged to be suitable as a spawning area for the experiment. Therefore, $2 \mathrm{~m} \times 5 \mathrm{~m}$ experimental and control areas were established in a riffle where we expected that spawning by Plecoglossus altivelis ryukyuensis should occur if we improve riverbed conditions by spawning ground construction. These two areas were adjacent to each other. Steel piles (50 $\mathrm{cm}$ length) were planted on the four corners of the control area using a wooden hammer, and a pink marking tape was tied to the piles to prevent people from stepping into the control areas during the course of the experiment.

River environmental survey and spawning ground construction. The rivers were surveyed before the spawning ground construction on November 25, 2011 in the Yakugachi and Kawauchi Rivers. Each area was scanned for more than 30 min for the presence of egg deposition. Six $25 \mathrm{~cm} \times 25 \mathrm{~cm}$ quadrats were randomly set in the $2 \mathrm{~m} \times 5 \mathrm{~m}$ experimental and control area, respectively. Environmental factors including riverbed hardness, substrate size, the number of caddisfly larvae, and the amount of silt deposited were quantified within each quadrat. To assess whether we selected the appropriate areas for spawning as experimental areas with regard to water depth and current velocity, these factors were also quantified even though spawning ground construction is not known to change these.

Water depth (cm) was measured using a fiberglass scale (Shinwa Rules Co., Ltd., Tsubame, Japan). Current velocity $(\mathrm{cm} / \mathrm{s})$ was measured three times using a propeller-type current meter (CR-11; Cosmo Riken, Kashiwara, Japan). The riverbed hardness was measured three times using the Yamanaka soil hardness tester (No. 351, Fujiwara Scientific 
Co., LTD). After these measurements were recorded, the surface layer of rivebed substrates within a $25 \mathrm{~cm} \times 25 \mathrm{~cm}$ quadrat was scooped out into a server sampler to measure substrate size, the number of caddisfly larvae, and the amount of silt deposited. The collected scoop was placed in a tray that measured $40 \mathrm{~cm}$ wide, $30 \mathrm{~cm}$ long, and $5 \mathrm{~cm}$ deep and the caddisfly larvae on the tray were counted. Afterwards, the tray was filled up with clear river water and the gathered silt was collected by straining the water using a small plankton net. This process was repeated two times, and $250 \mathrm{ml}$ of water with silt was preserved in a plastic bottle. A part of the gravel on the tray was transferred to another tray and they were arranged so that they did not overlap. River substrates on the tray were photographed along with a scale to help measure their long diameter at a later date. The caddisfly larvae and substrates were released at the sampling point after the operation.

Spawning ground construction using scoops and hoes in and around the experimental areas was undertaken jointly by researchers and resident volunteers on November 26, 2011 at Kawauchi River and on November 27, 2011 at Yakugachi River. During about one hour of construction, we attempted to wash away the silt and loosen the riverbed. Additionally, we removed rocks that were larger than $100 \mathrm{~mm}$ in long diameter from the experimental areas. Environmental factors were quantified within six randomly placed $25 \mathrm{~cm} \times 25 \mathrm{~cm}$ quadrats in the experimental areas on the day after the construction in both rivers. The control and experimental areas were scanned again for more than $30 \mathrm{~min}$ to detect the presence of eggs.

To assess whether Ryukyu-ayu utilized the experimental areas and how long the effect of spawning ground construction lasted, egg presence was checked by scanning the experimental and control areas for more than $30 \mathrm{~min}$ and the environmental factors were measured again within six randomly placed $25 \mathrm{~cm} \times 25 \mathrm{~cm}$ quadrats in both areas from December 17 to 19, 2011 (c.a. three weeks after the construction). In both the Yakugachi 
and the Kawauchi rivers, Ryukyu-ayu eggs were also found at the bottom of the riffles that were not used for the experiments. Therefore, environmental factors were measured in these areas as well within six randomly placed $25 \mathrm{~cm} \times 25 \mathrm{~cm}$ quadrats in both rivers (spawning area). During this period, between 1130 and $1230 \mathrm{~h}$, we snorkeled for approximately $30 \mathrm{~min}$ to record SL of Ryukyu-ayu (Yakugachi River: $n=65$; Kawauchi River: $n=31$ ). Water temperature was $14.4-16.5^{\circ} \mathrm{C}$ in the Yakugachi River and $15.6^{\circ} \mathrm{C}$ in the Kawauchi River from December 17 to 19, 2011. Further, on December 6-7, 2011 and on January 15, 2012, one of the authors (TY) again checked whether eggs were present in the 13 riffles. Utilization rate (\%) for each riffle was calculated as the number of surveys in which Ryukyu-ayu eggs were found on the bottom substrates divided by the total number of times the riffles were surveyed (i.e., 4 times).

In the laboratory, the long diameter $(\mathrm{mm})$ of river substrates ( $5 \mathrm{~mm}$ or more) were measured from the photographs acquired in the field using ImageJ 1.50i software (number of pebbles measured $=221 \pm 86 \mathrm{SD}$, range $=85-446, n=72$ quadrats) following the methods of Tsuruta et al. (2009). The collected silt was used to calculate the ash weight (i.e., the amount of inorganic substance) and the loss on ignition (i.e., the amount of organic substance) following the methods of Abe et al. (2008), and the total of these weights was used as the amount of silt $\left(\mathrm{mg} / \mathrm{m}^{2}\right)$.

Data analyses. Statistical analyses were performed using SPSS ver. 16.0 (IBM Corp., Armonk, NY, USA) and R ver. 3.3.2 (R Core Team 2016). Body size (SL) of Ryukyu-ayu was analyzed using two-way analysis of variance (two-way ANOVA, river x season). All environmental factors, except the number of caddisfly larvae, were analyzed using one-way analysis of variance (one-way ANOVA) with Tukey's honestly significance post-hoc (Tukey HSD) tests for multiple comparisons. The average substrate size, current velocity, and riverbed hardness for each quadrat were used for the analyses. For the analyses of the 
number of caddisfly larvae, we used the negative binomial generalized linear models (GLMs, link: log) in the lme4 package (Bates and Sarkar 2007) with sequential Bonferroni adjustments for multiple comparisons (Rice 1989). In this study, the raw data of riverbed hardness, i.e. the retraction length of spring $(\mathrm{mm})$ of the hardness tester, was used for the analyses instead of the penetrometer resistance $\left(\mathrm{P}, \mathrm{kg} / \mathrm{cm}^{2}\right)$ which was calculated from the retraction length of spring because $\mathrm{P}$ values were not normally distributed. All statistical tests were two-tailed, and alpha was set at 0.05 .

\section{Results}

Reproductive activity of Ryukyu-ayu and their body size. Of the 10 riffles investigated in November in the Yakugachi River, four riffles were used for spawning by Ryukyu-ayu (Table 1). Ryukyu-ayu eggs were found on the bottom substrate in six riffles during our study period. In the Kawauchi River, no eggs were found in the three riffles in November, but one of them contained eggs on the bottom substrates in December and January (Table 1). Contrary to our expectation, no eggs were found on the river substrate either in the experimental area of the Yakugachi River or the Kawauchi River (Table 1). This was also the case for the control areas. Body size of sexually mature Ryukyu-ayu did not differ between the rivers (two-way ANOVA, river x season: $F_{1,177}=0.25, P=0.62$; river: $F_{1,177}=$ $0.01, P=0.93)$, although their body size in December was slightly larger than those in November (season: $F_{1,177}=10.98, P=0.002$ ) (Yakugachi: $103.6 \mathrm{~mm} \pm 12.4 \mathrm{SD}$, range $=$ $80-130 \mathrm{~mm}, n=55$ in November; $109.7 \pm 10.8$, range $=90-130, n=65$ in December; Kawauchi: $104.3 \mathrm{~mm} \pm 10.4 \mathrm{SD}$, range $=80-130 \mathrm{~mm}, n=30$ in November; $108.7 \pm 7.2$, range $=100-120, n=31$ in December). 
Effects of spawning ground construction on the riverbed environment. Table 2 summarizes the results of changes in the six environmental factors before and after the spawning bed construction in the experimental, control, and spawning areas. In the experimental area of the Yakugachi River, as predicted, riverbed hardness significantly decreased on the day after the construction, and this construction effect continued even after three weeks (Fig. 2a). After the construction, the riverbed hardness in the experimental areas was quite similar to that in the spawning area. No changes in riverbed hardness were found in the control area, which were significantly higher than those in the spawning area (Fig. 2a). The amount of silt significantly increased from November to December in the control area, but was constantly low during the experiment in the experimental area (Fig. 2b). The amount of silt in the experimental area after construction did not differ from that of spawning area, but differed from that in control area in December (Fig. 2b). Contrary to our prediction, spawning ground construction did not affect the density of caddisfly larvae probably due to its low density across all study areas (Fig. 2c). Substrate size tended to decrease in the experimental area, although no statistical difference in substrate size before and after the construction was detected (Table 2).

As in the Yakugachi River, the positive effect of spawning bed construction on the riverbed environment was detected in the Kawauchi River (Table 2). Both riverbed hardness and the amount of silt significantly decreased after the construction in the experimental area, but not in the control area (Fig. 2d, e). Furthermore, the number of caddisfly larvae decreased soon after the construction, although this effect did not last for three weeks as in the control area (Fig. 2f). As in the Yakugachi River, substrate size tended to decrease in the experimental area of the Kawauchi River, although no statistical difference in substrate size was detected before and after the construction (Table 2).

Water depth and current velocity. Although water depth decreased from 
November to December, we did not find any difference between the control, experimental, and spawning areas in December in both the Yakugachi and the Kawauchi Rivers (Table 2). Current velocity also decreased from November to December in the Yakugachi and the Kawauchi Rivers (Table 2). Lower current velocity was detected in the experimental and control areas compared with spawning areas in December in both rivers.

\section{Discussion}

Increasing the quality of spawning habitat for endangered fish is particularly important in rivers where the original spawning grounds have been deteriorated by human activities. Since the endangered Ryukyu-ayu faces such a situation (Nishida 1988; Nishida et al. 1992; Shinomiya 2003; Tachihara 2015), verifying the effects of spawning bed construction on the reproduction and riverbed environments inhabited by this fish is needed to save the fish from extinction. Overall, the results of our field experiments show the positive effect of spawning ground construction on riverbed environment, which included reduced riverbed hardness, amount of silt, and the number of caddisfly larvae, although Ryukyu-ayu did not utilize the constructed areas as spawning sites. Although many studies have demonstrated the effects of spawning bed construction using bulldozers and power shovels on reproduction and riverbed environments in the subspecies ayu (see Introduction), to the best of our knowledge, the present study is the first to investigate if constructing spawning grounds manually using scoops and hoes improves the riverbed environment, making it more suitable for spawning of the Ryukyu-ayu.

In this study, we selected the riffle areas where we expected that Ryukyu-ayu would use as a spawning site if we improve riverbed condition by spawning ground 
construction. If the method of spawning ground construction and the choice of site creation are appropriate, it is predicted that Ryukyu-ayu should utilize the constructed areas but not the unconstructed control areas. In this study, however, no Ryukyu-ayu eggs were found in the constructed areas after three and seven weeks of construction in either of the rivers. Spawning was not observed in the control areas as well, suggesting that the riverbed environment is unlikely to be deteriorated by spawning ground construction. Furthermore, our analyses of riverbed environments revealed that, in the experimental areas, environmental parameters, such as riverbed hardness, silt cover, and caddisfly number (only in the Kawauchi River) improved after the creation and were similar to those in the spawning areas. In contrast, riverbed environments in the control areas did not change or deteriorate during the spawning season, resulting in the difference in environmental parameters between the control and spawning areas. Considering the fact that lower riverbed hardness and fewer caddisfly are the important factors for the spawning site selection by Ryukyu-ayu (Tsuruta et al. 2009; Ohtsuki et al. 2013), we can conclude that the effects of riverbed construction are positive and the method of spawning ground construction is appropriate.

Is there a possibility that the choice of creation sites was inappropriate? A recent study shows that spawning site selection by Ryukyu-ayu is also related to water depth and substrate size in addition to riverbed hardness, silt cover, and caddisfly number (Tsuruta et al. 2009). We found that, in both rivers, water depth and substrate size did not differ between the control, experimental and spawning areas. Although current velocity was significantly lower in the experimental and control areas than that in the spawning areas, previous studies have revealed the little importance of current velocity for spawning site selection by Ryukyu-ayu (Tsuruta et al. 2009). Therefore, there is a low possibility that selection of the construction site is not appropriate with regard to water depth, substrate size, 
and current velocity. However, during the breeding season, water depth and current velocity are variable due to rainfall, and such fluctuations might affect spawning site selection by the Ryukyu-ayu. To confirm the effect of these environmental fluctuations on spawning in Ryukyu-ayu, there is a need to continuously monitor the changes in the environmental factors and their spawning sites throughout the breeding season.

We avoided selecting as control and experimental areas those riffle areas that we judged as suitable for spawning, and indeed, Ryukyu-ayu utilized these for spawning. River bed construction in such areas may have an adverse effect on spawning of Ryukyu-ayu. In addition, if sufficient spawning grounds are available, the parent individual of Ryukyu-ayu may not use the artificially created spawning grounds. Indeed, fewer potential spawners were recorded in the study year; in November 2011, c.a. 9000 and 120 individuals were observed in the Yakugachi and Kawauchi Rivers, respectively, while the total fish observed in the island was c.a. 13000, which was the third lowest number recorded between 2010 and 2019 (Yonezawa et al., unpublished data). Thus, the selection of the construction site might be appropriate from this perspective and if available spawning ground is insufficient due to an increase in the number of spawners in certain years, Ryukyu-ayu can utilize the constructed areas as spawning site. Yearly monitoring of spawning sites and riverbed environment after spawning ground construction should be emphasized to elucidate its positive effect on the spawning of Ryukyu-ayu.

The body size of mature fish, which is generally related to the selection of the spawning site (e.g., Ishida 1961, 1962; Tsuruta et al. 2009), is different between the ayu and the Ryukyu-ayu. Indeed, as has been previously reported (Nishida and Uchimura 1987; Awata et al. 2012), body size of sexually mature Ryukyu-ayu examined in this study was 80-130 mm SL, which was much smaller than that reported for the ayu (e.g., 130-160 mm: Ishida 1961; 166-219 mm: Yamaguchi et al. 2014). However, spawning conditions of 
Ryukyu-ayu are comparable to those of ayu in riverbed hardness, substrate size, water depth, and current velocity (National Federation of Inland Water Fisheries Cooperative Associations 1993). Furthermore, spawning conditions of Ryukyu-ayu in this study was also quite similar to those investigated previously by Tsuruta et al. (2009). Thus, although applicable methods of spawning bed construction for Ryukyu-ayu were different from those for ayu, the goal of the construction is almost the same for both subspecies.

In summary, we have shown that spawning ground construction using scoops and hoes can improve the riverbed environment making it more suitable for spawning of Ryukyu-ayu. The spawning ground construction by researchers and resident volunteers in Amami-Oshima Island plays an important role not only to increase the availability of spawning sites for Ryukyu-ayu, but also to provide good environmental education for children (Abe et al. 2010). To reduce the risk of extinction of Ryukyu-ayu, we should continue to perform the spawning ground construction program every year. However, developing effective and practical ways of selecting sites for modification without obstructing the natural spawning in this fish is necessary.

\section{Compliance with ethical standards}

Ethical statement The field study was carried out in accordance with Animal Care and Use Committees at Niigata University and Osaka City University, and with the "Guidelines for the use of fishes in research" by the Ichthyological Society of Japan (http://www.fish-isj.jp/english/guidelines.html).

Acknowledgements The authors thank Akihiko Shinomiya, Katsunori Tachihara, Mutsumi Nishida, Hirohiko Takeshima, and Kenji Shimizu for project support and the children and their parents in Naze City and Uken village for their help in spawning ground construction 
of Ryukyu-ayu. We also acknowledge two anonymous reviewers for their helpful comments on an earlier version of this manuscript. We would like to thank Editage (https://www.editage.com) for English language editing. Financial support was provided by the River Fund in charge of the Foundation of River and Watershed Environment Management (FOREM), Japan (No. 23-1215-019). We declare that all field experiments comply with the current laws of Japan. 


\section{References}

Abe S, Iguchi K, Yonezawa T, Shinomiya A (2008) Flora and primary productivity of stream periphyton in habitats of Plecoglossus altivelis ryukyuensis in Amami-Oshima Island, Japan. Jpn J Phycol 56:9-16

Abe S, Iguchi K, Tamaki Y (2010) Attributes related to a personal evaluation of an endangered fish, Plecoglossus altivelis ryukyuensis, inhabiting streams on Amami-ohshima Island, Japan. Jap J Limnol 71:185-191

Aritomi A, Andou E, Yonezawa T, Kume G (2017) Monthly occurrence and feeding habits of larval and juvenile Ryukyu-ayu Plecoglossus altivelis ryukyuensis in an estuarine lake and coastal area of the Kawauchi River, Amami-oshima Island, southern Japan. Ichthyol Res 64:159-168

Awata S, Tsuruta T, Abe S, Tamaki Y, Iguchi K (2012) Feeding territory and variations in behavioural modes of algae-grazing fish Plecoglossus altivelis ryukyuensis (Ryukyu-ayu) in subtropical island streams. Ecol Freshw Fish 21:1-11

Bates D, Sarkar D (2007) 1me4: Linear Mixed-Effects Models Using S4 Classes. R package version $0.9975-13$ ed.

Hyodo M, Izumi K, Takemon Y, Sumi T (2014) Suitable riverbed for ayu spawning redds and effective gravel replenishment in the Tenryu River. Annuals Disas Prev Res Inst Kyoto Univ 57B:537-549

Iguchi K (1997) Risk taking release from nonnative stocks of ayu. Bull Natl Res Inst Aquacult Suppl 3:157-159

Ikeda M, Nunokawa M, Taniguchi N (2003) Lack of mitochondrial gene flow between populations of the endangered amphidromous fish Plecoglossus altivelis ryukyuensis inhabiting Amami-oshima Island. Fish Sci 69:1162-1168 
Ishida R (1961) On the spawning of the ayu, Plecoglossus altivelis T. \& S.-II. Relationships between the size of spawners and the size of gravels of the spawning bed. Bull Jap Soc Sci Fish 27: 1052-1057

Ishida R (1962) On the spawning of the ayu, Plecoglossus altivelis T. \& S.-III.

Relationships between the size of spawners and the depth of water of the spawning ground. Bull Jap Soc Sci Fish 28: 399-404

Izumi K, Takemon Y, Hyodo M, Kitamura Y, Sumi T (2016) Restoration of upwelling-zone in a secondary channel for creating spawning redds of ayu-fish in the Tenryu River. J Jap Soc Civil Eng Ser B1 72:I439-444

Kawanabe H (1972). An evolutionary aspect of the territoriality of ayu-fish, Plecoglossus altivelis, with the social structure at the southern end of its distribution. Jap J Ecol 22:141-149

Kishino T, Shinomiya A (2003) Upstream migration of Ryukyu-ayu Plecoglossus altivelis ryukyuensis in the Yakugachi River, Amami-oshima Island, Japan. Nippon Suisan Gakkaishi 69:624-631

Kishino T, Shinomiya A (2004) Seasonal appearance and size of newly-hatched larvae of Ryukyu-ayu Plecoglossus altivelis ryukyuensis in the Yakugachi and Kawauchi Rivers, Amami-oshima Island, southern Japan. Jpn J Ichthyol 51:149-156

Kondo M, Izumikawa K, Honda T, Ohtsuki K (2008) About a creation effect of artificial spawning ground that prepared land in the lake style dam decide and growth of a sand bar ayu Plecoglossus altivelis in the lake. Bull Fish Exp Sta Okayama Pref 23:35-44

Kondo M, Izumikawa K, Osakada K, Ohtsuki K, Sasada N (2011) The development of artificial spawning grounds for ayu, Plecoglossus altivelis altivelis. J Fish Tech $3: 137-145$

Ministry of Environment (2015) Red Data Book 2014-Threatened Wildlife of 
Japan_volume 4, Pisces—Brackish and Freshwater Fishes. Gyosei Corporation, Tokyo

Murase I, Kawakami T, Iguchi K (2018) Variation in growth performance of Ryukyu-ayu, Plecoglossus altivelis ryukyuensis, inferred from otolith analysis. Ichthyol Res $65: 482-487$

National Federation of Inland Water Fisheries Cooperative Associations (1993) Guide to creating spawning grounds for ayu Plecoglossus altivelis. Fisheries Agency, Tokyo

Newcombe CP, MacDonald DD (1991) Effects of suspended sediments on aquatic ecosystems. N Am J Fish Manag 11:72-82

Nishida M (1988) A new subspecies of the Ayu Plecoglossus altivelis (Plecoglossidae) from the Ryukyu Islands. Jpn J Ichthyol 35:236-242

Nishida M, Sawashi Y, Nishijima S, Azuma M, Fujimoto H (1992) Distribution and abundance of the Ryukyuan subspecies of the ayu Plecoglossus altivelis ryukyuensis: results of a survey made in 1986. Nippon Suisan Gakkaishi 58:199-206

Nishida M, Uchimura M (1987) Spawning activity of the ayu-fish Plecoglossus altivelis in rivers of Amami-oshima Island, the Ryukyus. Bull Coll Sci Univ Ryukyus 43:71-82

Ohtsuki K, Hirano K, Nihei Y (2013) Evaluation for spawning site of Ryukyu-ayu using an in-situ measurement method of riverbed-scour potential. J Jap Soc Civil Eng Ser. B1 (Hyd Eng) 69: I1231-I1236

R Core Team (2016) R: A language and environment for statistical computing. R Foundation for Statistical Computing, Vienna, Austria

Rice WR (1989) Analyzing tables of statistical tests. Evolution 43:223-225

Sawashi Y, Nishida M (1994) Genetic differentiation in populations of the Ryukyu-ayu Plecoglossus altivelis ryukyuensis on Amami-oshima Island. Jap J Ichthyol 41:253260 
Shinomiya A (1997) Ryukyu-ayu. In: Nagata Y, Hosoya K (eds) Circumstances in Endangered Japanese Freshwater Fishes and Their Production. Midori-Shobo, Tokyo, pp 36-47

Shinomiya A (2003) Ryukyu-ayu. In: Ministry of Environment (ed) Red Data Book 2003 - Threatened Wildlife of Japan — volume 4, Pisces_-Brackish and Freshwater Fishes. Gyosei Corporation, Tokyo, pp 30-31

Tachihara K (2015) Ryukyu-ayu. In: Ministry of Environment (ed) Red Data Book 2014 - Threatened Wildlife of Japan — volume 4, Pisces—Brackish and Freshwater Fishes. Gyosei Corporation, Tokyo, pp 52-53

Takahashi I, Terakado H, Sota K, Yasugi S, Murayama T, Fukui K (2015) Maintenance of spawning ground of Ayu, Plecoglossus altivelis altivelis, in the Gounokawa River, Shimane Prefecture in 2013. Rep Shimane Pref Fish Tech Cent 8:29-37

Takagi M, Shoji E, Taniguchi N (1999) Microsatellite DNA polymorphism to reveal genetic divergence in ayu, Plecoglossus altivelis. Fish Sci 65:507-512

Takeshima H, Iguchi K, Nishida M (2005) Unexpected ceiling of genetic differentiation in the control region of the mitochondrial DNA between different subspecies of the ayu Plecoglossus altivelis. Zool Sci 22:401-410

Tsuruta T, Abe S, Yonezawa T, Iguchi K (2009) Spawning condition of the Ryukyu-ayu (Plecoglossus altivelis ryukyuensis) in Amami-oshima Island. Ecol Civil Eng 12:109117

Yamaguchi K, Otomo Y, Kaniwa J (2014) Resources density and spawning habitat of Ayu Plecoglossus altivelis in the Kurome River. Agri Fore Fish Res Inf Tech Cent 13:79-8 
Table 1 Spawning acitivity by Ryukyu-ayu Plecoglossus altivelis ryukyuensis in the study areas of the Yakugachi and Kawauchi Rivers

\begin{tabular}{|c|c|c|c|c|c|c|}
\hline \multirow[b]{2}{*}{ Riffle no } & \multirow[b]{2}{*}{ Study area } & \multicolumn{5}{|l|}{ Survey date } \\
\hline & & $\begin{array}{l}\text { Nov. 24-27, } \\
2011\end{array}$ & Dec. 6-7, 2011 & $\begin{array}{l}\text { Dec. 17-19, } \\
2011\end{array}$ & Jan. 15, 2012 & $\begin{array}{l}\text { Utilization } \\
\text { rate }(\%)^{*}\end{array}$ \\
\hline \multicolumn{7}{|c|}{ Yakugachi River } \\
\hline YGRi. 1 & & - & - & - & - & 0 \\
\hline YGRi. 2 & & - & - & + & - & 25 \\
\hline YGRi. 3 & & - & - & - & - & 0 \\
\hline YGRi. 4 & & + & + & - & - & 50 \\
\hline YGRi. 5 & & + & - & - & + & 50 \\
\hline YGRi. 6 & Spawning area & + & + & + & + & 100 \\
\hline YGRi. 7 & & - & - & - & - & 0 \\
\hline YGRi. 8 & & - & - & + & - & 25 \\
\hline YGRi. 9 & & + & - & - & + & 50 \\
\hline YGRi. 10 & Experimental and control areas & - & - & - & - & 0 \\
\hline \multicolumn{7}{|c|}{ Kawauchi River } \\
\hline KWRi. 1 & Experimental and control areas & - & - & - & - & 0 \\
\hline KWRi. 2 & & - & - & - & - & 0 \\
\hline KWRi. 3 & Spawning area & - & + & + & + & 75 \\
\hline
\end{tabular}

Ryukyu-ayu eggs were found $(+)$ and not found (-) on the bottom substrates

*Utilization rate (\%) for each riffle was calculated as the number of surveys when Ryukyu-ayu eggs were found on the bottom substrates divided by the total number of surveys undertaken (i.e., 4) 
Table 2 Changes in environmental factors before and after the spawning ground construction for Ryukyu-ayu Plecoglossus altivelis ryukyuensis in Yakugachi and Kawauchi Rivers. Mean values \pm sem with different letters denote significant differences between groups, by Tukey HSD test or negative binomial GLM employing sequential Bonferroni adjustment ( $n=6$ for all groups)

\begin{tabular}{|c|c|c|c|c|c|c|c|c|c|}
\hline \multirow[t]{2}{*}{ Environmental factors } & \multicolumn{2}{|c|}{ Control area } & \multicolumn{3}{|c|}{ Experimental area } & \multirow[t]{2}{*}{ Spawning area } & \multicolumn{3}{|c|}{ Statistics } \\
\hline & Before & $\begin{array}{l}\text { After } 3 \\
\text { weeks }\end{array}$ & Before & $\begin{array}{l}\text { Immediately } \\
\text { after }\end{array}$ & $\begin{array}{l}\text { After } 3 \\
\text { weeks }\end{array}$ & & $F^{*}$ & $\chi^{2 * *}$ & $P$ \\
\hline \multicolumn{10}{|l|}{ Yakugachi River } \\
\hline Riverbed hardness (mm) & $30.1 \pm 1.3^{\mathrm{a}}$ & $29.9 \pm 0.8^{\mathrm{a}}$ & $28.2 \pm 1.7^{\mathrm{a}}$ & $15.3 \pm 0.5^{\mathrm{b}}$ & $19.3 \pm 2.8^{b}$ & $19.1 \pm 1.7^{\mathrm{b}}$ & 15.97 & - & $<0.0001$ \\
\hline Amount of silt $\left(\mathrm{g} / \mathrm{m}^{2}\right)$ & $0.65 \pm 0.12^{\mathrm{a}}$ & $5.00 \pm 1.20^{\mathrm{b}}$ & $0.89 \pm 0.30^{\mathrm{a}}$ & $0.44 \pm 0.08^{\mathrm{a}}$ & $0.84 \pm 0.13^{\mathrm{a}}$ & $2.04 \pm 0.79^{\mathrm{a}}$ & 8.22 & - & $<0.0001$ \\
\hline Number of caddisfly larvae $\left(/ 625 \mathrm{~cm}^{2}\right)$ & $0.00 \pm 0.00$ & $0.17 \pm 0.17$ & $0.33 \pm 0.21$ & $0.00 \pm 0.00$ & $0.17 \pm 0.17$ & $0.33 \pm 0.21$ & - & 5.55 & 0.35 \\
\hline Substrate size (mm) & $16.0 \pm 1.2^{\mathrm{a}}$ & $14.4 \pm 0.5^{\mathrm{ab}}$ & $13.5 \pm 0.8^{\mathrm{ab}}$ & $11.8 \pm 0.5^{\mathrm{bc}}$ & $12.8 \pm 0.3^{\mathrm{bc}}$ & $12.4 \pm 0.4^{\mathrm{bc}}$ & 5.04 & - & 0.002 \\
\hline Water depth $(\mathrm{cm})$ & $22.7 \pm 0.6$ & $18.3 \pm 0.7$ & $22.3 \pm 1.1$ & $24.0 \pm 2.6$ & $21.5 \pm 4.5$ & $19.8 \pm 1.3$ & 1.84 & - & 0.14 \\
\hline Current velocity $(\mathrm{cm} / \mathrm{sec})$ & $57.5 \pm 2.4^{\mathrm{ab}}$ & $44.5 \pm 2.1^{\mathrm{c}}$ & $68.9 \pm 2.1^{\mathrm{a}}$ & $59.9 \pm 2.4^{\mathrm{a}}$ & $46.1 \pm 2.9^{\mathrm{bc}}$ & $62.6 \pm 4.4^{\mathrm{a}}$ & 11.55 & - & $<0.0001$ \\
\hline \multicolumn{10}{|l|}{ Kawauchi River } \\
\hline Riverbed hardness (mm) & $20.5 \pm 1.0^{\mathrm{a}}$ & $18.5 \pm 1.3^{\mathrm{a}}$ & $18.8 \pm 1.8^{\mathrm{a}}$ & $13.0 \pm 1.3^{\mathrm{bc}}$ & $10.0 \pm 0.7^{\mathrm{c}}$ & $15.3 \pm 1.0^{\mathrm{ab}}$ & 10.56 & - & $<0.0001$ \\
\hline Amount of silt $\left(\mathrm{g} / \mathrm{m}^{2}\right)$ & $1.04 \pm 0.29^{\mathrm{ab}}$ & $1.64 \pm 0.55^{\mathrm{a}}$ & $1.04 \pm 0.20^{\mathrm{ab}}$ & $0.39 \pm 0.02^{b}$ & $0.46 \pm 0.10^{\mathrm{ab}}$ & $0.37 \pm 0.13^{\mathrm{ab}}$ & 3.10 & - & 0.02 \\
\hline Number of caddisfly larvae $\left(/ 625 \mathrm{~cm}^{2}\right)$ & $1.00 \pm 0.45^{\mathrm{ab}}$ & $2.67 \pm 0.88^{\mathrm{a}}$ & $0.67 \pm 0.33^{\mathrm{ab}}$ & $0.00 \pm 0.00^{\mathrm{b}}$ & $0.50 \pm 0.34^{\mathrm{ab}}$ & $0.33 \pm 0.33^{\mathrm{ab}}$ & - & 17.09 & 0.004 \\
\hline Substrate size (mm) & $12.4 \pm 0.9^{\mathrm{ab}}$ & $14.8 \pm 1.4^{\mathrm{a}}$ & $12.8 \pm 0.5^{\mathrm{ab}}$ & $11.3 \pm 1.3^{\mathrm{ab}}$ & $10.3 \pm 0.3^{\mathrm{bc}}$ & $10.3 \pm 0.3^{\mathrm{bc}}$ & 3.79 & - & 0.009 \\
\hline Water depth $(\mathrm{cm})$ & $25.2 \pm 1.0^{\mathrm{a}}$ & $19.8 \pm 1.2^{\mathrm{ab}}$ & $21.8 \pm 1.7^{\mathrm{ab}}$ & $23.8 \pm 1.0^{\mathrm{a}}$ & $15.1 \pm 2.3^{b}$ & $16.2 \pm 1.9^{b}$ & 6.43 & - & 0.0004 \\
\hline Current velocity $(\mathrm{cm} / \mathrm{sec})$ & $59.7 \pm 2.2^{\mathrm{ab}}$ & $43.1 \pm 6.6^{\mathrm{a}}$ & $57.2 \pm 2.9^{\mathrm{ab}}$ & $59.6 \pm 3.5^{\mathrm{ab}}$ & $42.7 \pm 3.8^{\mathrm{a}}$ & $67.1 \pm 6.6^{\mathrm{bc}}$ & 4.60 & - & 0.003 \\
\hline
\end{tabular}

*one-way ANOVA; **negative binomial GLM 


\section{Figure legends}

Fig. 1 Location of study sites in the two river systems of Amami-Oshima Island, Kagoshima, Japan. (a) The Kawauchi River that discharges into the East China Sea and the Yakugachi River that discharges into the Pacific Ocean. (b) Study sites in the Kawauchi and the Yakugachi Rivers

Fig. 2 Riverbed hardness, the amount of silt, and the number of caddisfly larvae in experimental, control, and spawning areas before and after the spawning ground construction. (a), (d) Riverbed hardness (mm). (b), (e) The amount of silt $\left(\mathrm{g} / \mathrm{m}^{2}\right)$. (c), (f) The number of caddisfly larvae Stenopsyche schmidi $\left(/ 625 \mathrm{~cm}^{2}\right)$. (a)-(c): Yakugachi River. (d)-(f): Kawauchi River. Means (+ sem) with different letters denote statistically significant differences ( $n=6$ for all groups; see Table 2 for statistics). $B$ Before construction, $I A$ immediately after construction, $A$ three weeks after construction 


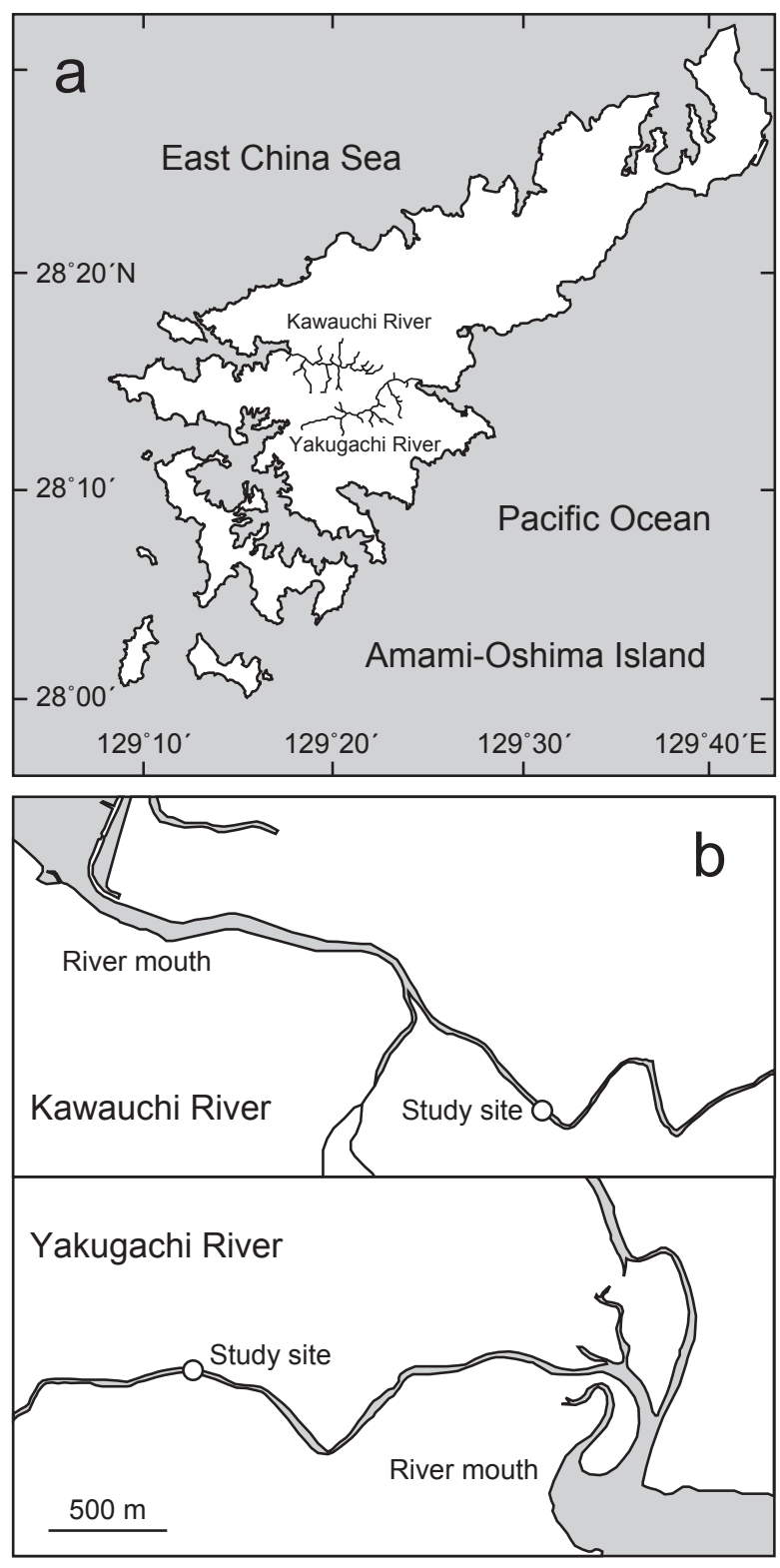



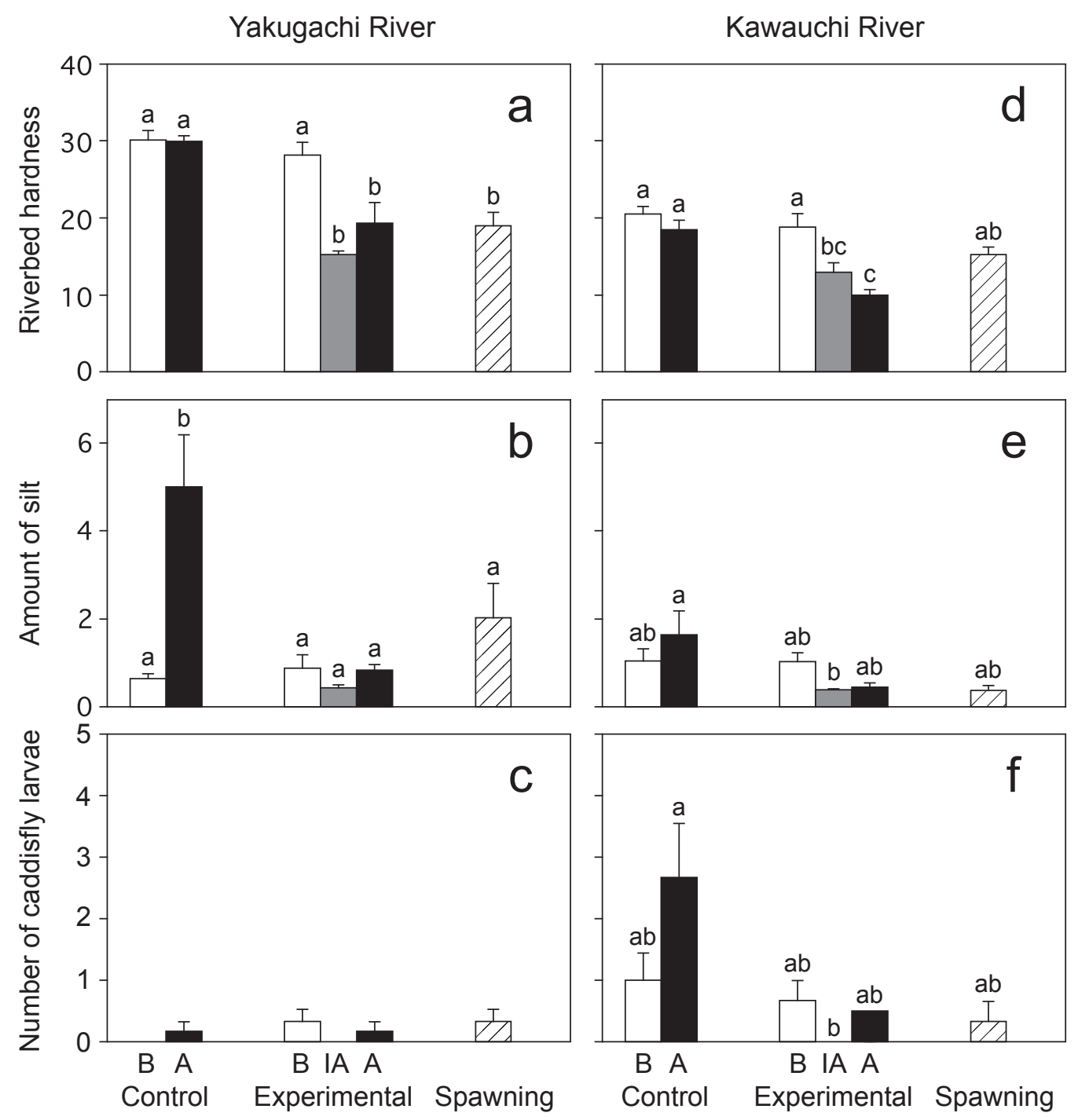